\title{
PENGARUH PERAWATAN PAYUDARA PADA IBU HAMIL TERHADAP PENINGKATAN PRODUKSI ASI DI WILAYAH KERJA PUSKESMAS KOTA KECAMATAN KOTA TERNATE TENGAH TAHUN 2016
}

\author{
Farida Alhadar*) ; Irawati Umaternate \\ Program Studi Diploma III Kebidanan ; Polteknik Kesehatan Kementrian Kesehatan Ternate \\ Jl. Cempaka Kel. Tanah Tinggi Barat Kec. Kota Ternate Selatan. Maluku Utara
}

\begin{abstract}
Abstrak
Perawatan payudara adalah suatu metode untuk meningkatkan produksi ASI. Penelitian ini bertujuan untuk mengetahui pengaruh perawatan payudara terhadap peningkatan produksi ASI pada ibu Post Partum di wilayah kerja Puskesmas Kota Kecamatan Kota Ternate Tengah Tahun 2016. Hasil penelitian menunjukkan bahwa 95\% dari 20 ibu hamil melakukan perawatan payudara jenis Senam Payudara/Pijatan Payudara, Ibu hamil yang melakukan perawatan payudara ASInya keluar lancar sebesar 95\%. Hasil Produksi ASI perhari pada hari pertama $10-30 \mathrm{cc} /$ hari adalah pada 8 orang $(40 \%)$ dan 20-40 cc/hari adalah juga pada 8 orang (40\%), pada hari kedua produksi ASI sebesar 40-60 cc/hari pada 10 orang (50\%), sedangkan pada hari ketiga produksi ASI meningkat menjadi 60-80 cc/hari pada 15 orang (75\%). Hasil penelitian juga menunjukkan bahwa ibu hamil yang tidak melakukan perawatan payudara produksi ASInya tidak lancar sebanyak 15 orang (75\%) dan ASI tidak keluar sebanyak 5 orang (25\%). Dari hasil penelitian tersebut disimpulkan bahwa ibu hamil lebih suka melakukan Perawatan Payudara dengan Senam Payudara/Pijatan Payudara; Perawatan Payudara dengan Senam Payudara/Pijatan Payudara produksi ASInya lebih lancar; Ibu hamil yang melakukan perawatan payudara berpengaruh signifikan terhadap peningkatan produksi ASI.
\end{abstract}

Kata Kunci : Perawatan ; Payudara ; Ibu Hamil ; Produksi ASI

\begin{abstract}
[EFFECT OF BREAST TREATMENT ON PREGNANT WOMAN ON IMPROVEMENT BREAST MILK PRODUCTION IN WORKING CENTER OF PUSKESMAS CITY TERNATE TENGAH CITY IN 2016] Breast care is a method to increase the breast milk production. This research is aimed to determine the effect of breast care on increasing milk production in Post-Partum mothers, in Puskesmas Ternate Tengah in 2016. The results showed that $95 \%$ of 20 pregnant mother perform breast care with Gymnastics or Massage. Pregnant mother who did breast care milk out as much as $95 \%$. The results of milk production on the first day $10-30 \mathrm{cc} /$ day, there are 8 people $(40 \%)$ and $20-40 \mathrm{cc} /$ day is also there are as many as 8 people $(40 \%)$, on the second day of milk production of $40-60 \mathrm{cc} /$ day there were 10 people (50\%), while on the third day of milk production increased to $60-80 \mathrm{cc} /$ day, as many as 15 people $(75 \%)$. The results also showed that pregnant mother who did not care for her breasts, as many as 15 people $(75 \%)$ milk production is not smooth and 5 people $(25 \%)$ milk did not come out. From the results of this study concluded that pregnant mother prefer to do breast care with Gymnastics or Massage on her breasts. Breast Care with Gymnastics or Breast Massage results in more smooth milk production. Pregnant mother who do breast care have a significant effect on increasing milk production.
\end{abstract}

Keywords: Care; Breast ; Pregnant mother ; Breast milk production

\section{Pendahuluan}

*) Farida Alhadar

E-mail: farida_alhadar@gmail.com
ASI mengandung semua zat gizi dan cairan yang dibutuhkan untuk memenuhi seluruh gizi bayi pada 6 bulan pertama kehidupannya. Pada umur 6 sampai 12 bulan, ASI masih merupakan makanan utama bayi, 
karena mengandung lebih dari $60 \%$ kebutuhan bayi. Guna memenuhi semua kebutuhan bayi, perlu ditambah dengan Makanan Pendamping ASI (MPASI). Jika bayi tidak mau minum ASI, maka kebutuhan gizi bayi tidak akan terpenuhi secara baik dan bayi akan mudah terkena penyakit. (Saryono dan Pramitasari, 2009). Untuk mengatasi masalah tersebut salah satunya adalah memberikan pengarahan tentang perawatan payudara kepada ibu hamil sebaiknya dilakukan pada usia kehamilan 18 minggu sampai usia kehamilan 40 minggu atau masa kehamilan Trimester II dan III (Geniofan, 2010), disamping melakukan Health Education melalui penyuluhan-penyuluhan pada ibu hamil yang disertai demonstrasi cara perawatan payudara sebelum dan setelah melahirkan dengan benar, serta peragaan tentang perawatan payudara pada saat kontrol kehamilan dan kunjungan masa nifas, dimana penyuluhan tepat pada waktu ibu mengembangkan kemampuan dalam mengambil keputusan yang merupakan informasi keterpaduan menalar ilmiah dan sistematis (Anwar, 2005). Selain itu juga bisa melalui leaflet, alat peraga, poster-poster dan promosi melalui radio dan media lainnya. Upaya ini dapat meningkatkan kemampuan ibu dalam perawatan payudara secara baik dan benar sebagai upaya preventif terhadap masalah menyusui sehingga proses menyusui dapat berjalan dengan lancar dan merupakan upaya untuk meningkatkan derajat kesehatan ibu dan bayi (Saryono dan Pramitasari, 2009).

Penurunan produksi ASI pada hari-hari pertama setelah melahirkan teknik menyusui kurang baik (Pertiwi, 2012). Hasil penelitian yang dilakukan perawatan payudara pada ibu post partum dengan kelancaran pengeluaran ASI di desa Karang Duren Kabupaten Semarang bahwa hasil penelitian ini menunjukkan adanya hubungan antara perawatan payudara pada ibu post partum sangat berperan dalam kelancaran produksi ASI. Penelitian yang dilakukan oleh Pertiwi pada tahun 2012 dengan judul "Faktor-faktor yang mempengaruhi proses laktasi ibu dengan bayi usia 0 - 6 bulan di Desa Cibeusi Kecamatan Jatinangor". Hasil penelitian menunjukkan bahwa $47 \%$ ibu dapat disebabkan oleh kurangnya rangsangan hormone prolaktin dan oksitosin yang menunjukkan bahwa konsidi dan perawatan payudara kurang baik, $55 \%$ ibu menunjukkan bahwa kondisi dan perawatan baik penelitian yang dilakukan oleh
Solichah pada tahun 2011 dengan judul "Hubungan dengan kelancaran pengeluaran ASI dengan hasil $p=0,0007$ (Sholichah, 2011).

Dari laporan hasil Survei Demografi dan Kesehatan Indonesia (SDKI, 2007) diusia lebih dari 25 tahun sepertiga wanita di Dunia (38\%) didapati tidak menyusui bayinya karena terjadi pembengkakan payudara, dan di Indonesia angka cakupan ASI eksklusif mencapai 32,3\% ibu yang memberikan ASI eksklusif pada anak mereka. Survei Demografi dan Kesehatan Indonesia (SDKI) tahun 2008 - 2009 menunjukkan bahwa 55\% ibu menyusui mengalami mastitis dan puting susu lecet, kemungkinan hal tersebut disebabkan karena kurangnya perawatan payudara selama kehamilan. Berdasarkan penelitian di Surabaya pada tahun 2004 menunjukkan $46 \%$ ibu yang memberikan ASI eksklusif pada anaknya dan yang melakukan perawatan payudara sekitar 34\% (Varney, H., Kriebs, J \& Gegor, C). Di wilayah Kota Ternate ditemukan bahwa cakupan ASI eksklusif pada tahun 2014 baru mencapai 73\% dari target MDGs tahun 2015 yaitu sebesar $80 \%$. Meskipun perbedaannya tidak terlalu besar namun tidak berarti pemerintah dapat mengabaikan sebaliknya hal ini haruslah dimaknai sebagai tantangan sekaligus peluang untuk keberhasilan yang lebih baik lagi.Tenaga kesehatan dalam hal ini bidan mesti menganggap bahwa tugas mereka kedepan lebih berat sebab masih akan muncul ibu-ibu hamil baru dan memerlukan pendidikan kesehatan sesuai dengan kebutuhannya. Disisi lain ditemukan fakta dari hasil wawancara dengan beberapa bidan koordinator bahwa perawatan payudara pada ibu hamil yang dilakukan selama ini adalah masih berorientasi pada pemberian penyuluhan atau dengan kata lain lebih ditekankan pada peningkatan pengetahuan dan belum secara spesifik pada implementasi, juga belum pernah dilakukan evaluasi terhadap hasil penyerapan pengetahuan pasca penyuluhan sehingga sulit untuk mengukur dan menilai seberapa besar penerapan pengetahuan mereka akan perawatan payudara.

\section{Metode}

Tujuan penelitian ini adalah untuk mengetahui pengaruh perawatan payudara pada ibu hamil terhadap peningkatan produksi ASI pada ibu post partum di Puskesmas Kota Kecamatan Kota Ternate Tengah. 
Penelitian ini merupakan jenis penelitian Case Control dengan desain Prospektif. Penelitian ini dilaksanakan berlokasi di Wilayah Kerja Puskesmas Kota Kecamatan Kota Ternate Tengah tahun 2016.

Populasi dalam penelitian ini adalah ibu hamil trimester ke tiga yang melakukan pemeriksaan kehamilan yang ada di Puskesmas Kota Kecamatan Kota Ternate Tengah Tahun 2016.

Sampel pada penelitian ini di pilih secara acak (Sistematic random sampling) berdasarkan jumlah ibu hamil trimester ketiga yang datang untuk memeriksakan kehamilannya di Puskesmas Kota Kecamatan Kota Ternate Tengah tahun 2016.

Besar sampelnya di tentukan dengan menggunakan rumus berikut (Notoatmojo, 2010):

$$
\begin{aligned}
& \mathrm{n}=\frac{N}{1+(d)^{2}} \\
& \text { Keterangan : } \\
& \mathrm{n}=\text { Besar Sampel } \\
& \mathrm{N}=\text { Besar Populasi } \\
& \mathrm{d}^{2}=\text { Tingkat Kepercayaan }
\end{aligned}
$$

\section{Hasil dan Pembahasan}

Hasil penelitian diperoleh dari data hasil observasi yang telah dianalisis dengan Fisher's Exact Test yang kemudian disajikan dalam bentuk tabel disertai dengan narasi sebagai berikut :

Tabel 1. Distribusi Responden Berdasarkan Jenis Perawatan Payudara Yang Dilakukan

\begin{tabular}{c|c|c}
\hline Perawatan Payudara & $\mathbf{N}$ & $\%$ \\
\hline Pemberian Nutrisi & 1 & 5.0 \\
Senam payudara/Pijatan payudara & 19 & 95.0 \\
Total & \multicolumn{2}{|c|}{$\mathbf{2 0}$} \\
\hline
\end{tabular}

Berdasarkan tabel 1. didapatkan bahwa pada kelompok ibu hamil yang melakukan perawatan payudara, sebanyak $95 \%$ (19 orang) yang melakukan Senam Payudara/pijatan payudara selebihnya 5\% (1 orang) adalah jenis perawatan payudara dengan pemberian nutrisi.

Tabel 2. Distribusi Responden Berdasarkan Hasil yang Didapatkan Selama Pengamatan Pada Ibu Hamil Yang Melakukan Perawatan Payudara

\begin{tabular}{ccc}
\hline Hasil & N & \% \\
\hline ASI Lancar & 19 & 95.0 \\
\hline ASI Tdk Lancar & 1 & 5.0 \\
\hline Total & $\mathbf{2 0}$ & $\mathbf{1 0 0 . 0}$
\end{tabular}

Berdasarkan tabel 2. didapatkan bahwa pada kelompok ibu yang melakukan perawatan payudara dengan ASI lancar sebanyak 95\% (19 orang) dan yang ASI tidak lancar sebanyak $5 \%$ (1 orang).

Tabel 3. Distribusi Responden Berdasarkan Hasil Produksi ASI (cc/Hari) Di Hari Pertama Pada ibu Hamil Yang Melakukan Perawatan Payudara.

\begin{tabular}{ccc} 
Produksi ASI (cc/Hari) Hari $\mathbf{1}$ & $\mathbf{N}$ & $\%$ \\
\hline $10-30$ & 8 & 40.0 \\
$10-40$ & 2 & 10.0 \\
$20-40$ & 8 & 40.0 \\
$30-60$ & 1 & 5.0 \\
$5-10$ & 1 & 5.0 \\
\hline Total & $\mathbf{2 0}$ & $\mathbf{1 0 0 . 0}$ \\
\hline
\end{tabular}

Berdasarkan tabel 3. didapatkan bahwa pada kelompok ibu yang melakukan perawatan payudara dengan jumlah ASI yang keluar pada hari ke-1 yang jumlahnya 10-30 cc sebanyak $40 \%$ (8 orang), $10-40$ cc sebanyak $10 \%$ (2 orang), $20-40$ cc sebanyak $40 \%$ (8 orang), 30-60 cc sebanyak 5\% (1 orang) dan 5-10 cc sebanyak $5 \%$ (1 orang).

Tabel 4. Distribusi Responden Berdasarkan Hasil Produksi ASI (cc/Hari) Di Hari Kedua Pada Ibu Yang Melakukan Perawatan Payudara

\begin{tabular}{ccc}
$\begin{array}{c}\text { Produksi ASI (cc/Hari) } \\
\text { Hari 2 }\end{array}$ & N & $\%$ \\
\hline $30-50$ & 2 & 10.0 \\
$30-60$ & 5 & 25.0 \\
$30-70$ & 2 & 10.0 \\
$40-60$ & 10 & 50.0 \\
$60-80$ & 1 & 5.0 \\
\hline Total & $\mathbf{2 0}$ & $\mathbf{1 0 0 . 0}$ \\
\hline
\end{tabular}


Berdasarkan tabel 4. didapatkan bahwa pada kelompok ibu yang melakukan perawatan payudara dengan jumlah ASI yang keluar pada hari II dengan jumlah 30-50 cc sebanyak 10\% ( 2 orang), $30-60$ cc sebanyak 25\% (5 orang), 30-70 cc sebanyak 10\% (2 orang), 40-60 cc sebanyak $50 \%$ (10 orang) dan $60-80 \mathrm{cc}$ sebanyak $5 \%$ (1 orang).

Tabel 6. Distribusi Responden Berdasarkan Hasil Pengamatan Pada Kelompok Ibu Hamil Yang Tidak Melakukan Perawatan Payudara

\begin{tabular}{ccc} 
Hasil & N & \% \\
\hline ASI keluar tidak lancar & 15 & 75.0 \\
ASI tidak keluar & 5 & 25.0 \\
Total & $\mathbf{2 0}$ & $\mathbf{1 0 0 . 0}$ \\
\hline
\end{tabular}

Berdasarkan tabel 6. didapatkan bahwa pada kelompok ibu yang tidak melakukan perawatan payudara sebagian besar yaitu $75 \%$ (15 orang) yang ASI keluar tapi tidak lancar dan sebanyak 25\% (5 orang) ASI tidak keluar.

Tabel 7. Data Crosstabs Antara Jenis Perawatan Payudara Dengan Hasil Pengamatan Pada Ibu Hamil Yang Melakukan Perawatan Payudara

\begin{tabular}{cccc}
\hline \multirow{2}{*}{$\begin{array}{c}\text { Jenis Perawatan } \\
\text { Payudara }\end{array}$} & \multicolumn{2}{c}{ Hasil } & \\
\cline { 2 - 3 } & $\begin{array}{c}\text { ASI } \\
\text { lancar }\end{array}$ & $\begin{array}{c}\text { ASI } \\
\text { tidak } \\
\text { lancar }\end{array}$ & Total \\
\hline Pemberian Nutrisi & 1 & 0 & 1 \\
\hline $\begin{array}{c}\text { Senam Payudara/ } \\
\text { Pijatan Payudara }\end{array}$ & 18 & 1 & 19 \\
\hline Total & $\mathbf{1 9}$ & $\mathbf{1}$ & $\mathbf{2 0}$ \\
\hline
\end{tabular}

Berdasarkan tabel 7. Responden yang melakukan perawatan payudara dengan jenis senam Payudara/Pijatan Payudara, hasilnya adalah ASI lancar sebanyak 19 responden dan yang tidak lancar hanya 1 responden.

Tabel 8. Analisis Pengaruh Pemberian Perawatan Payudara Pada Ibu Hamil Terhadap Peningkatan Produksi ASI

\begin{tabular}{ccc}
\hline \multirow{2}{*}{ Hasil } & \multicolumn{2}{c}{ Perawatan Payudara } \\
\cline { 2 - 3 } & $\mathbf{N}$ & $\%$ \\
\hline ASI lancar & 19 & 95.0 \\
ASI tidak lancar & 1 & 5.0 \\
Total & 20 & 100.0 \\
& \multicolumn{2}{c}{ Tidak Melakukan } \\
Hasil & $\mathbf{N}$ & $\%$ \\
\cline { 2 - 3 } & 15 & 75.0 \\
\hline ASI keluar tidak lancar & 5 & 25.0 \\
ASI tidak keluar & 20 & 100.0 \\
Total & \multicolumn{2}{c}{0.001} \\
\hline Fisher's Exact Test & \multicolumn{2}{c}{}
\end{tabular}

Berdasarkan tabel 8. didapatkan hasil signifikansi (Fisher's Exact Test) perbandingan hasil antara ibu yang melakukan perawatan payudara dengan membandingkan dengan nilai alfa $(\alpha)$ 0.05. Dari hasil perbandingan tersebut didaptkan nilai sig 0.001 < alfa (a) 0.05, hal tersebut menunjukkan bahwa perawatan payudara signifikan pengaruhnya terhadap produksi ASI.

Pembahasan dari hasil yang keluar adalah $10-30$ cc sebanyak 40 persen (8 orang), $10-40$ cc sebanyak 10 orang.

Perawatan payudara selama kehamilan adalah salah satu bagian penting yang harus diperhatikan sebagai persiapan untuk menyusui nantinya. Payudara perlu dipersiapkan sejak masa kehamilan sehingga bila bayi lahir dapat segera berfungsi dengan baik pada saat diperlukan.

Berdasarkan tabel 1. diatas dapat diketahui bahwa $95 \%$ atau sebanyak 19 orang menggunakan jenis perawatan senam payudara atau pijatan payudara dan $5 \%$ atau hanya 1 orang yang melakukan perawatan payudara dengan jenis pemberian nutrisi pada payudara. Hal ini menunjukkan bahwa kebanyakan ibu hamil lebih berminat menggunakan jenis perawatan payudara dengan metode senam payudara atau pijatan payudara.

Hasil penelitian sebagaimana yang disajikan pada tabel 2, diperoleh bahwa 95\% atau 19 orang ibu hamil yang melakukan perawatan payudara produksi ASInya lancar dan hanya $5 \%$ atau hanya 1 orang yang produksi ASInya tidak lancar.

Produksi ASI di hari pertama, kedua dan ketiga disajikan dalam tabel 3, 4 dan 5, dimana pada hari pertama didapatkan bahwa pada kelompok ibu yang melakukan perawatan payudara dengan jumlah ASI persen (2 orang), 
20-40 cc sebanyak 40\% (8 orang), 3060 cc sebanyak 5\% (1 orang) dan 5-10 cc sebanyak $5 \%$ (1 orang). Hal ini memberi makna bahwa ibu hamil yang melakukan perawatan payudara produksi ASInya pada hari pertama tertinggi mencapai 30-60 cc/hari namun hanya $5 \%$ dari jumlah ibu hamil atau hanya 1 orang dan lebih banyak ibu hamil pada hari pertama memproduksi ASI antara 10-30 cc/hari dan 20$40 \mathrm{cc}$ atau berjumlah masing masing 8 orang. Pada hari kedua (tabel 4) jumlah ASI yang keluar dengan jumlah 30-50 cc sebanyak 10\% (2 orang), 30-60 cc sebanyak 25\% (5 orang), 30-70 cc sebanyak 10\% (2 orang), 40-60 cc sebanyak $50 \%$ (10 orang) dan $60-80 \mathrm{cc}$ sebanyak $5 \%$ ( 1 orang). Hal ini menunjukkan bahwa pada hari kedua separuh dari ibu hamil atau 50\% ibu hamil memproduksi ASI 40-60 cc. Selanjutnya pada hari ketiga (tabel 5) didapatkan bahwa pada kelompok ibu yang melakukan perawatan payudara dengan jumlah ASI yang keluar jumlahnya 50-90 cc sebanyak $10 \%$ (2 orang), $60-80$ cc sebanyak $75 \%$ (15 orang), 70-90 cc sebanyak 10\% (2 orang) dan 80-120 cc sebanyak 5\% (1 orang). Hal ini menunjukkan bahwa produksi asi pada ibu hamil lebih banyak terjadi pada hari ketiga yaitu sebanyak 15 ibu hamil atau $75 \%$ dengan jumlah 60-80 cc. Produksi ASI yang terus meningkat ini disebabkan karena seringnya bayi menyusui. Hal ini sesuai teori yang mengatakan bahwa semakin sering seorang ibu menyusui si bayi, semakin banyak pula ASI yang diproduksi oleh tubuh.

Berdasarkan tabel 6. didapatkan bahwa pada kelompok ibu yang tidak melakukan perawatan payudara sebagian besar yaitu $75 \%$ (15 orang) yang ASI keluar tapi tidak lancar dan sebanyak 25\% (5 orang) ASI tidak keluar. Hal ini menunjukkan bahwa ibu hamil yang tidak melakukan perwatan payudara jelas berpengaruh terhadap kelancaran ASI bahkan tidak keluar sama sekali. Kenyataan ini sangat menguatkan argumen landasan teori bahwa ibu hamil yang tidak melakukan perawatan payudara akan menghambat pemberian ASI pada bayi antara lain puting susu tidak menonjol sehingga bayi sulit menghisap, produksi ASI sedikit sehingga tidak cukup dikonsumsi bayi, infeksi pada payudara, payudara bengkak atau bernanah, muncul benjolan di payudara dan gizi kurang.

Berdasarkan tabel 7, ibu hamil yang melakukan perawatan payudara dengan jenis senam Payudara/Pijatan Payudara, hasilnya adalah ASI lancar sebanyak 19 responden dan yang tidak lancar hanya 1 responden. Hasil ini menunjukkan bahwa ibu hamil yang melakukan perawatan payudara dengan senam Payudara/Pijatan Payudara hasilnya adalah ASI lebih lancar. Dari 20 orang ibu hamil hanya 1 orang saja yang ASInya tidak lancar. Hal ini dikarenakan Senam Payudara/Pijatan Payudara memiliki beberapa keunggulan dari perawatan dengan senam payudara atau pijatan payudara adalah setelah persalinan Asi keluar lancar, puting menonjol, aereola bersih dan bayi dapat menyusui dengan baik bahkan pada 1 responden produksi ASInya berlebihan sehingga bisa ditampung ke botol susu sebagai ASI perah.

Berdasarkan tabel 8. didapatkan hasil signifikansi (Fisher's Exact Test) yaitu perbandingan hasil antara ibu yang melakukan perawatan payudara dan yang tidak melakukan perawatan payudara dengan membandingkan nilai alfanya (a) 0.05. Dari hasil perbandingan tersebut didapatkan nilai sig $0.001<$ alfa (a) 0.05, hal tersebut menunjukkan bahwa perawatan payudara signifikan pengaruhnya terhadap produksi ASI. Hasil ini didukung oleh hasil penelitian yang dilakukan oleh Ulfin I. Djumadi di tahun 2014, dengan judul Hubungan antara Perawatan Payudara dengan Produksi ASI pada Ibu Primipara di Wilayah Kerja Puskesmas Wongkaditi Kota Gorontalo menyimpulkan bahwa sebagian besar ibu primipara yang melakukan perawatan payudara dengan baik, menghasilkan produksi ASI yang banyak. Selanjutnya setelah diukur dengan menggunakan uji Fisher's Exact Test, diperoleh hasil bahwa nilai Exact Sig. (2-sided) sebesar $0.002<0.05$ dari nilai yang didapatkan maka dapat yang berarti terdapat hubungan antara perawatan payudara dengan produksi ASI pada Ibu Primipara. Hasil penelitian itu juga diketahui bahwa hasil analisis proporsi yaitu sebanyak 23 ibu primipara $(67,6 \%)$ memiliki perawatan payudara baik yang produksi ASInya banyak.

Uraian hasil penelitian yang diperoleh ini juga didukung oleh teori dan pendapat para ahli antara lain menurut (Saryono, 2009), bahwa perawatan payudara saat kehamilan memiliki beberapa manfaat, antara lain: menjaga kebersihan payudara terutama kebersihan puting susu; melenturkan dan menguatkan puting susu sehingga memudahkan bayi untuk menyusu, merangsang kelenjar-kelenjar air susu sehingga 
produksi ASI banyak dan lancar dapat mendeteksi kelainan-kelainan payudara secara dini dan melakukan upaya untuk mengatasinya mempersiapkan mental (psikis) ibu untuk menyusui.

\section{Simpulan dan Saran} bahwa:

Dari hasil penelitian tersebut disimpulkan

1.ibu hamil lebih suka melakukan Perawatan Payudara dengan Senam Payudara/Pijatan Payudara.

2. Perawatan Payudara dengan Senam Payudara/Pijatan Payudara produksi ASInya lebih lancar.

3. Ibu hamil yang melakukan perawatan payudara berpengaruh signifikan terhadap peningkatan produksi ASI.

\section{Ucapan Terimakasih}

Ucapan terimakasih disampaikan kepada Direktur Poltekkes Kemenkes Semarang, Ketua Jurusan, Ketua Prodi, keluarga, mitra sejawat, responden, dan semua pihak yang terlibat dalam penelitian ini.

\section{Daftar Pustaka}

Astari, Djuminah, 2013. Hubungan perawatan payudara masa Antenatal dengan kecepatan sekresi ASI Post Partum Primipara

Azwar, Saifuddin. 2005. Sikap Manusia Teori dan Pengukurannya. Yogyakarta : Pustaka Pelajar.

Machfoedz, Ircham dan Suryani, Eko. 2008. Pendidikan Kesehatan bagian dari Promosi Kesehatan.Yogyakarta : Fitramaya.

Notoatmodjo, Soekidjo. 2010. Promosi Kesehatan $\mathcal{E}$ Ilmu Perilaku.Jakarta : PT Rineka Cipta.

Nugroho, dkk. 2014. Buku Ajar Asuhan Kebidanan 3 Nifas.Yogyakarta : Nuha Medika.

Nursalam, (2011). Konsep dan Penerapan Metodologi Penelitian Ilmu Keperawatan, Pedoman Skripsi, Tesis, dan Instrumen Penelitian Keperawatan Edisi 2. Jakarta : Salemba Medika.

Profil Kesehatan Provinsi Maluku Utara, (2013). Profil Kesehatan Provinsi Maluku Utara 2012 (online). http://www.depkes.go.id. Tanggal 07 Maret 2016. Jam 16.00 WIT.

Profil Kementerian Kesehatan, (2015). Profil Kesehatan Indonesia 2014 http://www.depkes.go.id. Tanggal 08 Maret 2016. Jam 15.00 WIT.

Putriningrum, 2013. Hubungan tingkat pengetahuan Ibu primigravida tentang perawatan payudara dengan tindakan merawat payudaradi BPS Sunarsi Sumber lawang Sragen

Setiawan A, Saryono, (2011). Metodologi Penelitian Kebidanan D III, D IV, S1, dan S2. Yogyakarta : Nuha Medika.

Ulfin I, Djumadi, (2014). Hubungan antara Perawatan Payudara dengan Produksi ASI pada Ibu Primipara di Wilayah Kerja Puskesmas Wongkaditi Kota Gorontalo

Wulandari, Handayani. 2011. Asuhan Kebidanan Ibu Masa Nifas.Yogyakarta : Gosyen Publishing.

Vika Wulandari, Sulastri. 2012. Hubungan antara tingkat pengetahuan ibu Primigravida dengan perilaku perawatan payudara pada saat hamil di Wilayah Kerja Puskesmas Karangdowo Klaten. 